\title{
Managing Cardiovascular Risk in Type 2 Diabetes: What Do the Cardiovascular Outcome Trials Mean for Australian Practice?
}

\author{
Gary Deed (1) · John J. Atherton · Michael d'Emden - Roy Rasalam • \\ Anita Sharma $\cdot$ Andrew Sindone
}

Received: May 31, 2019 / Published online: July 10, 2019

(C) The Author(s) 2019

\begin{abstract}
Understanding the implications of cardiovascular (CV) outcomes data of glucose-lowering agents on the management of type 2 diabetes mellitus can be challenging for many primary practitioners. Amongst different classes of diabetes medications assessed for CV safety, several agents within the sodium-glucose transport protein-2 inhibitor and glucagon-like peptide- 1 receptor agonists classes have demonstrated $\mathrm{CV}$
\end{abstract}

Enhanced Digital Features To view enhanced digital features for this article go to https://doi.org/10.6084/ m9.figshare.8320166.

\section{G. Deed $(\bowtie)$}

Mediwell Medical Clinic, Coorparoo, QLD, Australia e-mail: drgarydeed@outlook.com

\section{J. J. Atherton · M. d'Emden}

Royal Brisbane and Women's Hospital, University of Queensland School of Medicine, Herston, QLD, Australia

R. Rasalam

James Cook University, Douglas, QLD, Australia

A. Sharma

Platinum Medical Centre, Chermside, QLD,

Australia

A. Sindone

Concord Hospital, University of Sydney, Concord,

NSW, Australia risk reduction. Applying the trial findings to patients typically seen in clinical practice, such as those with established CV disease and those with multiple $\mathrm{CV}$ risk factors without established CV disease, requires further clarity. To bridge this gap in our current knowledge, the aim of this review was to utilise expert-driven opinions on common case scenarios and practical recommendations on the most appropriate choice of agents, according to an individual patient's clinical risk profile (CV and kidney disease), treatment preference and reimbursement environment from an Australian perspective.

Funding: Boehringer Ingelheim Australia.

Keywords: Cardiovascular; DPP-IV inhibitor; GLP-1RAs; Hospitalisation; Kidney; MACE; Management; Outcome; Risk; SGLT-2 inhibitors; Type 2 diabetes

\section{CLINICAL BURDEN OF DIABETES IN AUSTRALIA}

As the worldwide prevalence of type 2 diabetes mellitus (T2DM) increases, with approximately $8.8 \%$ of the adult population (20-79 years of age) affected, 1.5 million Australians are currently estimated to have T2DM [1, 2]; it remains one of the most common chronic conditions managed in primary care and the number of 
patients with $\mathrm{T} 2 \mathrm{DM}$ is estimated to continue to rise. Indeed, $>1$ in 10 patients aged 45-64 years who present to primary practice have been diagnosed with T2DM and typically have 9 primary practitioner visits a year, 4 of which are related to diabetes [3]. Most of these individuals are also diagnosed with other chronic conditions, such as arthritis, depression and notably cardiovascular disease (CVD), including heart failure [4], and have associated risk factors of hypertension and dyslipidaemia. Collectively, all serve to increase the clinical burden of T2DM further [5].

\section{Compliance with Ethics Guidelines}

This article is based on previously conducted studies and does not contain any studies with human participants or animals performed by any of the authors.

\section{IDENTIFYING CARDIOVASCULAR RISK IN T2DM IN PRIMARY PRACTICE}

In Australia, as many as two in three adults with T2DM have CVD [2]. Indeed, CVD is a major cause of death in these individuals [6]. This clinical burden makes it imperative that primary practitioners attempt to reduce the $\mathrm{CV}$ risk of patients with T2DM with agents that have evidence to improve $\mathrm{CV}$ outcomes.

The risk of $\mathrm{CV}$ morbidity and mortality is disproportionately higher in those with T2DM than in those without [7]. While T2DM was considered to be "cardiovascular risk equivalent" to those without T2DM but who had experienced a prior coronary event [8], a more contemporary view is that there is large heterogeneity in CV risk among T2DM populations $[9,10]$. Special populations such as smokers, the elderly, Aboriginal and Torres Strait Islanders, those of Asian and Pacific descent and those with chronic kidney disease (CKD) have a higher absolute risk of CVD. Women and younger adults with diabetes have a disproportionately higher relative risk of CVD compared with those without diabetes; furthermore, those who have T2DM and preexisting CVD have a much higher risk of CV death compared with those with T2DM who do not already have CVD [11].

Consequently, guidelines recommend $\mathrm{CV}$ risk stratification of patients into one of three categories-low $(<10 \%)$, moderate $(10-15 \%)$ and high $(>15 \%)$-to better identify those who would benefit from a more or less intensive prevention and management strategy [12]. For Australian clinicians, for information on how to calculate the absolute CV risk, refer to the National Vascular Disease Prevention Alliance initiative at: https:// www.cvdcheck.org.au where you can access the calculator and supporting resources.

\section{MODIFYING CARDIOVASCULAR RISK IN T2DM}

\section{Is Glycaemic Control Important in CV Risk?}

There are compelling and established data supporting the benefit of long-term glycaemic control in reducing the risk of microvascular complications in T2DM. Whether lowering blood glucose translates into similar macrovascular CV benefits has been a major focus in the past decade. Studies, such as the United Kingdom Prospective Diabetes Study (UKPDS) and the Diabetes Control and Complications Trial/ Epidemiology of Diabetes Interventions and Complications (DCCT-EDIC), suggested a 'legacy effect' in newly diagnosed individuals with diabetes, whereby good glycaemic management improved longer-term CV outcomes [13, 14]. However, other studies, such as Action in Diabetes and Vascular Disease (ADVANCE), Action to Control Cardiovascular Risk in Diabetes (ACCORD) and Veterans Affairs Diabetes Trial (VADT) found that intensive glycaemic lowering did not result in favourable $\mathrm{CV}$ outcomes and rather, in some cases, increased the risk of both total mortality and CV death [15-17].

The potential risks of intensive glucose-lowering are further supported by two separate meta-analyses of CV outcome trials (CVOT) in T2DM $[18,19]$. While both report a modest and significant reduction in major CV events, such 
as MI, following tighter glycaemic control, they found that the CV benefit was at the expense of a significant increase in hypoglycaemia events and no mortality benefit. Collectively, these data present a reminder that patient characteristics, particularly duration of diabetes, and the 'legacy effect' may influence the choice of an individual's glycated haemoglobin $\left(\mathrm{HbA}_{1 \mathrm{c}}\right)$ target and that this target in turn may change with long-term, optimal glycaemic control in advancing diabetes.

Australian Diabetes Society guidelines recommend an $\mathrm{HbA}_{1 \mathrm{c}}$ target of $7 \%(53 \mathrm{mmol} / \mathrm{mol})$ for most T2DM patients [20]. A more stringent $\mathrm{HbA}_{1 \mathrm{c}}$ target of $6.5 \%(48 \mathrm{mmol} / \mathrm{mol})$ may be considered if it can be achieved without hypoglycaemia except where contraindications exist such as known CVD, long duration of T2DM and if having existing episodes of severe hypoglycaemia. For women planning pregnancy, the goal is to achieve an $\mathrm{HbA}_{1 \mathrm{c}}$ target of $6.0 \%$ $(42 \mathrm{mmol} / \mathrm{mol})$. Less ambitious targets are recommended for elderly patients and those with lowered awareness of hypoglycaemia or major comorbidities $\left(\mathrm{HbA}_{1 \mathrm{c}}\right.$ of $\left.8.0 \% ; 64 \mathrm{mmol} / \mathrm{mol}\right)$ [20]. For patients with limited life expectancy or at a palliative care stage, there are no targets and the goal is to keep them 'safe' and relatively asymptomatic.

\section{Can the Choice of Glucose-Lowering Medication Impact CV Outcome?}

Metformin has been established as baseline therapy for type 2 diabetes, based on evidence for a role in the reduction of microvascular complications from the seminal UKPDS study and an emergent macrovascular benefit on long-term analysis [21]. Unlike newer agents, funded CV outcome trails of similar quality do not exist, however, as it has been used for $\geq 60$ years in clinical practice, confidence exists that it certainly does not increase CV risk and, based upon on the extended data from UKPDS (in a small cohort of obese patients), is likely to benefit CVD outcomes [22].

In the case of sulphonylureas, their association with CV risk factors, hypoglycaemia and weight gain is widely recognised [23]. However, controversy exists with respect to their association with $\mathrm{CV}$ outcomes and mortality, especially in patients with an elevated risk of CVD or established CVD. While observations of increased CVD events and raised mortality have questioned the use of sulphonylureas either as monotherapy or in combination with metformin vs. other glucose-lowering agents [24-27], some meta-analyses and systematic reviews have provided reassurance on the $\mathrm{CV}$ safety of this drug class $[28,29]$, alongside the ADVANCE study [15], and the recent announcement of the non-inferiority results of the CAROLINA study [30]. Despite this, with more favourable CV profiles of newer agents emerging, ADA/EASD guidelines have shifted away from recommending the early use of sulphonylureas in patients with established CVD [31].

The impact of more recent glucose-lowering agents on CVD risk had, until recently, been less well known $[32,33]$. There is now increasing evidence from CVOTs that demonstrates CV benefits with certain diabetes medications, in particular the sodium-glucose transport protein2 (SGLT-2) inhibitors and glucagon-like peptide-1 receptor agonists (GLP-1RAs) [34]. In recognition of these findings, there has been a contemporary shift in the recommended strategy for CV risk reduction in managing T2DM that extends beyond glucose control.

A summary of recommendations from Australian as well as several international guidelines is outlined in BOX 1 [31, 34-38]. 
Box 1: Multifactorial approach to CV risk reduction in T2DM

\begin{tabular}{|c|c|}
\hline Approach & Guideline target/individualised goal recommendations \\
\hline \multirow[t]{2}{*}{$\mathrm{HbA}_{1 \mathrm{c}}$ control } & $\mathrm{HbA}_{1 \mathrm{c}} \leq 7 \%(53 \mathrm{mmol} / \mathrm{mol})^{*}$ \\
\hline & ${ }^{*}$ Target customised according to age and comorbidities \\
\hline \multirow[t]{3}{*}{ Blood pressure control } & $<140 / 90 \mathrm{mmHg}$ for patients with T2DM and hypertension \\
\hline & $<130 / 80 \mathrm{mmHg}$ for patients with albuminuria/proteinuria \\
\hline & Measure at every routine visit and on separate days to diagnose and confirm hypertension \\
\hline \multirow[t]{7}{*}{ Cholesterol management } & Total cholesterol $<4.0 \mathrm{mmol} / 1$ \\
\hline & $\mathrm{HDL}-\mathrm{C} \geq 1.0 \mathrm{mmol} / \mathrm{l}$ \\
\hline & $\mathrm{LDL}-\mathrm{C}<2.0 \mathrm{mmol} / 1(<1.8 \mathrm{mmol} / 1$ if $\mathrm{CVD}$ is present $)$ \\
\hline & Triglycerides $<2.0 \mathrm{mmol} / \mathrm{l}^{*}$ \\
\hline & $\begin{array}{l}\text { Assess cholesterol levels at time of T2DM diagnosis, at initial review and every } 5 \text { years if } \\
<40 \text { years or more frequently if indicated }\end{array}$ \\
\hline & $\begin{array}{l}\text { Assess cholesterol levels at time of statin or initiation of other cholesterol-lowering therapy at } \\
4-12 \text { weeks after initiation or a change in dose and then annually to help monitor response } \\
\text { and adherence to medication }\end{array}$ \\
\hline & $\begin{array}{l}{ }^{*} \text { Note: Canadian guidelines on dyslipidaemia in T2DM stipulate a target of triglyceride } \\
<1.5 \mathrm{mmol} / \mathrm{l}[35]\end{array}$ \\
\hline \multirow{4}{*}{$\begin{array}{l}\text { Therapies with proven } \mathrm{CV} \\
\text { benefit }\end{array}$} & Blood pressure medications ( $\mathrm{ACEi} / \mathrm{ARB}$ favoured if evidence of $\mathrm{CKD}$ ) \\
\hline & Cholesterol-lowering agents-statin, ezetimibe, PCSK9 inhibitors \\
\hline & Antiplatelet agents-low-dose aspirin (in established CVD) \\
\hline & Glucose-lowering therapies-SGLT-2 inhibitors and GLP-1RAs \\
\hline \multirow[t]{4}{*}{$\begin{array}{l}\text { Screening for } \\
\text { complications }\end{array}$} & $\begin{array}{l}\text { Cardiac-ECG, longer term monitoring or opportunistic screening may be needed if a patient } \\
\text { is }>65 \text { years or has a detectable dysrhythmia or is symptomatic [38] }\end{array}$ \\
\hline & Kidney-assess eGFR and ACR annually, or more frequently if indicated \\
\hline & $\begin{array}{l}\text { Eye disease-refer for retinal examination every } 2 \text { years (once a year if T2DM }>15 \text { years or } \\
\text { HBA }_{1 \mathrm{c}}>8 \% \text {, presence of diabetes complications or poorly controlled BP and lipids) }\end{array}$ \\
\hline & Foot-assess monofilament/vibration annually or more frequently if indicated \\
\hline \multirow[t]{3}{*}{ Lifestyle interventions } & Smoking cessation -0 cigarettes/day \\
\hline & $\begin{array}{l}\text { Exercise-approximately } 30 \mathrm{~min} \text { of moderate physical activity on most if not all days of the } \\
\text { week (total } \geq 150 \mathrm{~min} / \text { week) }\end{array}$ \\
\hline & Alcohol consumption $-\leq 2$ standard drinks $(20 \mathrm{~g})$ per day for men and women \\
\hline
\end{tabular}

\section{A REVIEW OF THE EVIDENCE}

In 2008, the FDA issued a mandate requiring all new glucose-lowering medications to demonstrate CV safety prior to approval [32]. Consequently, there are now a multitude of completed and ongoing CVOTs (Table 1) [34], particularly for the dipeptidyl peptidase-IV 
Table 1 CVOTs of glucose-lowering medications. Adapted from Cefalu et al. [34]

\begin{tabular}{|c|c|c|c|}
\hline Drug class & Cardiovascular outcome trial & Completed & Ongoing \\
\hline \multicolumn{4}{|c|}{$\alpha$-Glucosidase inhibitor } \\
\hline Acarbose & Acarbose Cardiovascular Evaluation (ACE) & $\checkmark$ & \\
\hline \multicolumn{4}{|l|}{ DPP-IV Inhibitor } \\
\hline Alogliptin & $\begin{array}{l}\text { Examination of Cardiovascular Outcomes with } \\
\text { Alogliptin versus Standard of Care (EXAMINE) }\end{array}$ & $\checkmark$ & \\
\hline \multirow[t]{2}{*}{ Linagliptin } & $\begin{array}{l}\text { Cardiovascular and Renal Microvascular Outcome Study } \\
\text { with Linagliptin in Patients with Type } 2 \text { Diabetes } \\
\text { Mellitus (CARMELINA) }\end{array}$ & $\checkmark$ & \\
\hline & $\begin{array}{l}\text { Cardiovascular Outcome Trial of Linagliptin versus } \\
\text { Glimepiride in Type } 2 \text { Diabetes (CAROLINA) }\end{array}$ & $\checkmark$ & \\
\hline Saxagliptin & $\begin{array}{l}\text { Saxagliptin Assessment of Vascular Outcomes Recorded } \\
\text { in Patients with Diabetes Mellitus-Thrombolysis in } \\
\text { Myocardial Infarction (SAVOR-TIMI 53) }\end{array}$ & $\checkmark$ & \\
\hline Sitagliptin & $\begin{array}{l}\text { Trial Evaluating Cardiovascular Outcomes with } \\
\text { Sitagliptin (TECOS) }\end{array}$ & $\checkmark$ & \\
\hline \multicolumn{4}{|c|}{ GLP-1 receptor agonist } \\
\hline Albiglutide & $\begin{array}{l}\text { Effect of Albiglutide, When Added to Standard Blood } \\
\text { Glucose Lowering Therapies, on Major Cardiovascular } \\
\text { Events in Subjects With Type } 2 \text { Diabetes Mellitus } \\
\text { (HARMONY) }\end{array}$ & $\checkmark$ & \\
\hline Exenatide & $\begin{array}{l}\text { Exenatide Study of Cardiovascular Event Lowering } \\
\text { (EXSCEL) }\end{array}$ & $\checkmark$ & \\
\hline Dulaglutide & $\begin{array}{l}\text { Researching Cardiovascular Events With a Weekly } \\
\text { Incretin in Diabetes (REWIND) }\end{array}$ & $\checkmark$ & \\
\hline Liraglutide & $\begin{array}{l}\text { Liraglutide Effect and Action in Diabetes: Evaluation of } \\
\text { Cardiovascular Outcome Results (LEADER) }\end{array}$ & $\checkmark$ & \\
\hline Lixisenatide & $\begin{array}{l}\text { Evaluation of Lixisenatide in Acute Coronary Syndrome } \\
\text { (ELIXA) }\end{array}$ & $\checkmark$ & \\
\hline Semaglutide & $\begin{array}{l}\text { Trial to Evaluate Cardiovascular and Other Long-term } \\
\text { Outcomes With Semaglutide in Subjects With Type } 2 \\
\text { Diabetes (SUSTAIN-6) }\end{array}$ & $\checkmark$ & \\
\hline \multicolumn{4}{|l|}{ Insulin } \\
\hline Insulin degludec & $\begin{array}{l}\text { A Trial Comparing Cardiovascular Safety of Insulin } \\
\text { Degludec Versus Insulin Glargine in Patients With } \\
\text { Type } 2 \text { Diabetes at High Risk of Cardiovascular } \\
\text { Events (DEVOTE) }\end{array}$ & $\checkmark$ & \\
\hline
\end{tabular}


Table 1 continued

\begin{tabular}{|c|c|c|c|}
\hline Drug class & Cardiovascular outcome trial & Completed & Ongoing \\
\hline Insulin glargine & $\begin{array}{l}\text { Outcome Reduction with an Initial Glargine } \\
\text { Intervention (ORIGIN) }\end{array}$ & $\boldsymbol{V}$ & \\
\hline \multicolumn{4}{|l|}{ SGLT-2 inhibitor } \\
\hline \multirow[t]{2}{*}{ Canagliflozin } & $\begin{array}{l}\text { Canagliflozin Cardiovascular Assessment Study } \\
\text { (CANVAS) }\end{array}$ & $\boldsymbol{\nu}$ & \\
\hline & $\begin{array}{l}\text { Evaluation of the Effects of Canagliflozin on Renal and } \\
\text { Cardiovascular Outcomes in Participants With } \\
\text { Diabetic Nephropathy (CREDENCE) }\end{array}$ & & $\checkmark$ \\
\hline \multirow[t]{3}{*}{ Dapagliflozin } & $\begin{array}{l}\text { Multicenter trial to evaluate the effect of dapagliflozin on } \\
\text { the incidence of cardiovascular events (DECLARE- } \\
\text { TIMI 58) }\end{array}$ & $\checkmark$ & \\
\hline & $\begin{array}{l}\text { A Study to Evaluate the Effect of Dapagliflozin on Renal } \\
\text { Outcomes and Cardiovascular Mortality in Patients } \\
\text { With Chronic Kidney Disease (DAPA-CKD) }\end{array}$ & & $\checkmark$ \\
\hline & $\begin{array}{l}\text { DAPA-HF (Study to Evaluate the Effect of } \\
\text { Dapagliflozin on the Incidence of Worsening Heart } \\
\text { Failure or Cardiovascular Death in Patients With } \\
\text { Chronic Heart Failure) }\end{array}$ & & $\checkmark$ \\
\hline \multirow[t]{3}{*}{ Empagliflozin } & $\begin{array}{l}\text { Empagliflozin Cardiovascular Outcome Event Trial in } \\
\text { Type } 2 \text { Diabetes Mellitus Patients (EMPA-REG } \\
\text { OUTCOME) }\end{array}$ & $\checkmark$ & \\
\hline & $\begin{array}{l}\text { Empagliflozin Outcome Trial in Patients With Chronic } \\
\text { Heart Failure With Preserved Ejection Fraction } \\
\text { (EMPEROR-Preserved) }\end{array}$ & & $\checkmark$ \\
\hline & $\begin{array}{l}\text { Empagliflozin Outcome Trial in Patients With Chronic } \\
\text { Heart Failure with Reduced Ejection Fraction } \\
\text { (EMPEROR-Reduced) }\end{array}$ & & $\checkmark$ \\
\hline Ertugliflozin & $\begin{array}{l}\text { Cardiovascular Outcomes Following Ertugliflozin } \\
\text { Treatment in Type } 2 \text { Diabetes Mellitus Participants } \\
\text { With Vascular Disease (VERTIS CV) }\end{array}$ & & $\checkmark$ \\
\hline \multicolumn{4}{|l|}{ TZD } \\
\hline Pioglitazone & Insulin Resistance Intervention After Stroke (IRIS) & $\boldsymbol{V}$ & \\
\hline
\end{tabular}

(DPP-IV) inhibitors, GLP-1RAs and SGLT-2 inhibitors. These trials have informed our approach as to which glucose-lowering medications may be safe in the context of T2DM and CVD.

\section{Which Glucose-Lowering Medications Offer CV Protection?}

DPP-IV inhibitors Collectively, these appear to have a neutral effect on CV outcomes (Table 2). 
Table 2 Summary of DPP-IV inhibitors CVOTs

\begin{tabular}{|c|c|c|c|}
\hline \multicolumn{4}{|l|}{ DPP-IV inhibitors } \\
\hline TGA-approved & Reimbursed & CVOT & CV effect \\
\hline $\begin{array}{l}\text { Alogliptin }[41,42] \\
\quad(\text { Nesina })\end{array}$ & $\checkmark$ & $\begin{array}{l}\text { EXAMINE }(n=5380) \\
\text { High CV risk population } \\
\text { ACS requiring hospitalisation within 15-90 days } \\
\text { before randomisation } \\
\text { Primary end point: } 3 \text {-point MACE } \\
\text { Non-inferiority design } \\
\text { Alogliptin vs. PBO }\end{array}$ & $\begin{array}{l}\text { Neutral for MACE } \\
\text { HR } 0.96(95 \% \text { CI }<1.16) \text {; } \\
p=0.32\end{array}$ \\
\hline $\begin{array}{l}\text { Linagliptin }[30,61] \\
\quad \text { (Trajenta) }\end{array}$ & $\checkmark$ & $\begin{array}{l}\text { CAROLINA }(n=6033)[29] \\
\text { High risk CV and/or CKD population } \\
\text { Established CVD or increased risk of CVD } \\
\text { Primary end point: 3-point MACE } \\
\text { Non-inferiority design } \\
\text { Linagliptin vs. glimepiride } \\
\text { CARMELINA ( } n=6979)[61] \\
\text { High CV risk population } \\
\text { Existing CKD, established CVD or both } \\
\text { Primary end point: } 3 \text {-point MACE } \\
\text { Non-inferiority design } \\
\text { Linagliptin vs.PBO }\end{array}$ & $\begin{array}{l}\text { Neutral for MACE } \\
\text { HR } 1.02(95 \% \text { CI } \\
0.89-1.17) ; p<0.001\end{array}$ \\
\hline $\begin{array}{l}\text { Saxagliptin }[39,40] \\
\text { (Onglyza) }\end{array}$ & $\checkmark$ & $\begin{array}{l}\text { SAVOR-TIMI }(n=16,492) \\
\text { High CV risk population } \\
\text { History of established CVD or multiple risk } \\
\text { factors for vascular disease } \\
\text { Primary end point: 3-point MACE } \\
\text { Superiority and non-inferiority design } \\
\text { Saxagliptin vs. PBO }\end{array}$ & $\begin{array}{l}\text { Neutral for MACE } \\
\text { HR } 1.0 \text { (95\% CI 0.89-1.12); } \\
p=0.99\end{array}$ \\
\hline $\begin{array}{l}\text { Sitagliptin [60] } \\
\text { (Januvia) }\end{array}$ & $\checkmark$ & $\begin{array}{l}\text { TECOS }(n=14,671) \\
\text { High CV risk population } \\
\text { Pre-existing CVD } \\
\text { Primary end point: 4-point MACE } \\
\text { Superiority and non-inferiority design } \\
\text { Sitagliptin vs.PBO }\end{array}$ & $\begin{array}{l}\text { Neutral for MACE } \\
\text { HR } 0.98(95 \% \text { CI } \\
0.88-1.09) ; p<0.001\end{array}$ \\
\hline
\end{tabular}


Table 2 continued

DPP-IV inhibitors

\begin{tabular}{|c|c|c|c|}
\hline TGA-approved & Reimbursed & CVOT & CV effect \\
\hline Vildagliptin (Galvus) & $\checkmark$ & NO CVOT reported & Unknown \\
\hline
\end{tabular}

3-point MACE: CI confidence interval; CV death, nonfatal MI or nonfatal stroke; 4-point MACE: CV death, nonfatal MI, nonfatal stroke or hospitalisation for unstable angina; $A C S$ acute coronary syndrome, $C V D$ cardiovascular disease, $H F$ heart failure, $H R$ hazard ratio, $M A C E$ major adverse $C V$ effect, $P B O$ placebo

None of the trials demonstrated an increase in the primary composite end point of major adverse cardiovascular events (MACE), which included CV death, nonfatal MI, nonfatal stroke with or without hospitalisation for unstable angina. There was a very small absolute increase in cases of hospitalisation for heart failure $(0.7 \%)$ associated with the use of saxagliptin [39]. The increase in risk was highest in patients at the highest absolute risk of heart failure, i.e., those with established CVD or multiple CVD risk factors [40]. A similar trend was seen with alogliptin but not with the other DPP-IV inhibitors [41, 42]. Overall, DPP-IV inhibitors satisfied the regulatory $\mathrm{CV}$ safety criteria for T2DM but appear to have no positive impact on $\mathrm{CV}$ outcomes.

GLP-1RAs CVOT data are available for three of the five GLP-1RAs approved in Australia (Table 3). While not yet registered in Australia, semaglutide also has published CV data [43]. The SUSTAIN-6 study reported a protective effect on 3-point MACE, driven by a significant reduction in nonfatal stroke [HR 0.61; (95\% CI $0.38-0.99 ; p=0.04)]$ and a nonsignificant reduction in nonfatal MI [HR: 0.74; $(95 \% \mathrm{CI}$ $0.51-1.08 ; p=0.12)$ ]. No difference in the risk of CV death was noted [43]. In contrast, lixisenatide (ELIXA study) had a neutral effect on CV outcomes [44], whereas the EXSCEL study assessing the once-weekly exenatide preparation just failed to reach significance for $\mathrm{CV}$ benefit with a $9 \%$ reduction in events (CI $0.83-1.00 ; p=0.06$ ) although a significant reduction in cardiovascular mortality was observed (Table 3) [45]. With liraglutide in the LEADER study, fewer patients experienced CVrelated death, nonfatal MI or nonfatal stroke compared with placebo: $13 \%$ (608 of 4668 patients) vs. $14.9 \%$ (694 of 4672 patients), respectively (Table 3) [46]. The CVOT of dulaglutide is yet to be published [47], although the full data set is anticipated in 2019 [48].

The heterogenous effects on MACE within this drug class may reflect differences in the patient populations and designs of the CVOTs as well as being potentially related to the pharmacokinetic and structural differences between the individual GLP-1RAs. Nevertheless, CV safety for all the approved agents in this class has been demonstrated in high-risk T2DM patients [43-46]. In terms of safety and tolerability, transient nausea and vomiting are common side effects among patients initiated on GLP-1RAs yet are usually self-limiting with the longer acting agents. Retinopathy was seen in small numbers with semaglutide in cardiac safety trials [43].

SGLT-2 inhibitors Three out of four TGA-approved agents in this class have CVOT data (Table 4). Both canagliflozin and empagliflozin demonstrated a CV benefit in terms of reducing the primary end point of MACE, while dapagliflozin was found to have a non-significant reduction in this end point [49-51]. Ertugliflozin is yet to report $\mathrm{CV}$ outcome data (Table 1). In the EMPA-REG OUTCOME study, participants had established CVD (76\% with coronary artery disease; $47 \%$ with a history of MI). The primary composite end point of death from CV causes, nonfatal MI or nonfatal stroke occurred in $10.5 \%$ (490 of 4687) receiving empagliflozin (pooled doses of $10 \mathrm{mg}$ and $25 \mathrm{mg}$ ) vs. $12.1 \%$ (282 of 2333 ) in the placebo group, translating into a $14 \%$ relative risk reduction in these events (Table 4 ). This reduction was primarily driven by a $38 \%$ relative risk reduction in CV-related death [50]. 
Table 3 Summary of GLP-1RA CVOTs

\begin{tabular}{|c|c|c|c|}
\hline \multicolumn{4}{|l|}{ GLP-1RAs } \\
\hline $\begin{array}{l}\text { TGA- } \\
\text { approved }\end{array}$ & Reimbursed & CVOT & CV effect \\
\hline $\begin{array}{l}\text { Dulaglutide } \\
\text { [47] } \\
\text { (Trulicity) }\end{array}$ & $\checkmark$ & $\begin{array}{l}\text { REWIND }(n=9901) \\
\text { High CV risk population } \\
\text { Prior CV event, evidence of CVD or } \geq 2 \mathrm{CV} \text { risk } \\
\text { factors } \\
\text { Primary end point: } 3 \text {-point MACE } \\
\text { Dulaglutide vs. PBO }\end{array}$ & Just published \\
\hline $\begin{array}{l}\text { Exenatide BD } \\
\text { (Byetta) }\end{array}$ & $\checkmark$ & NO CVOT reported & Unknown \\
\hline $\begin{array}{l}\text { Exenatide QW } \\
\text { [45] } \\
\text { (Bydureon) }\end{array}$ & $\checkmark$ & $\begin{array}{l}\text { EXSCEL }(n=14,752) \\
\text { High CV risk population } \\
\text { Pre-existing CVD } \\
\text { Primary end point: 3-point MACE } \\
\text { Non-inferiority design } \\
\text { Exenatide QW vs. PBO }\end{array}$ & $\begin{array}{l}\text { Neutral for MACE } \\
\text { HR } 0.91 \text { (95\% CI } 0.83-1.00) \\
p<0.001 \text { for noninferiority }\end{array}$ \\
\hline $\begin{array}{l}\text { Liraglutide } \\
\quad[46] \\
\text { (Victoza) }\end{array}$ & $x$ & $\begin{array}{l}\text { LEADER }(n=9340) \\
\text { High CV risk population } \\
\text { Pre-existing CVD; kidney disease; HF; or } \geq 1 \mathrm{CV} \text { risk } \\
\text { factor } \\
\text { Primary end point: 3-point MACE } \\
\text { Superiority and non-inferiority design } \\
\text { Liraglutide vs. } \mathrm{PBO}\end{array}$ & $\begin{array}{l}\text { Benefit for MACE } \\
\text { HR } 0.87 \text { (95\% CI } 0.78-0.97) \\
p<0.001 \text { for noninferiority, } \\
p=0.01 \text { for superiority }\end{array}$ \\
\hline $\begin{array}{l}\text { Lixisenatide } \\
\text { [44] } \\
\text { (Lyxumia) }\end{array}$ & $x$ & $\begin{array}{l}\text { ELIXA }(n=6068) \\
\text { High CV risk population } \\
\text { Pre-existing CVD } \\
\text { Primary end point: 4-point MACE } \\
\text { Superiority and non-inferiority design } \\
\text { Lixisenatide vs. PBO }\end{array}$ & $\begin{array}{l}\text { Neutral for MACE } \\
\text { HR } 1.02(95 \% \text { CI } 0.89-1.17) \\
p<0.001 \text { for noninferiority }\end{array}$ \\
\hline
\end{tabular}


Table 3 continued

\begin{tabular}{|c|c|c|c|}
\hline \multicolumn{4}{|l|}{ GLP-1RAs } \\
\hline $\begin{array}{l}\text { TGA- } \\
\text { approved }\end{array}$ & Reimbursed & CVOT & CV effect \\
\hline \multirow{6}{*}{$\begin{array}{l}\text { Semaglutide }^{\mathrm{a}} \\
\text { [43] }\end{array}$} & \multirow[t]{6}{*}{$\checkmark$} & SUSTAIN-6 $(n=3297)$ & Benefit for MACE \\
\hline & & High CV risk population & HR 0.74 (95\% CI $0.58-0.95)$ \\
\hline & & $\begin{array}{l}\text { Established CVD, chronic heart failure or CKD } \\
\geq \text { stage } 3 \text { or } \geq 60 \text { years of age with at least one } \mathrm{CV} \\
\text { risk factor }\end{array}$ & $p<0.001$ for noninferiority \\
\hline & & Primary end point & \\
\hline & & Non-inferiority design & \\
\hline & & Semaglutide vs.PBO & \\
\hline
\end{tabular}

$B D$ twice daily, $C K D$ chronic kidney disease, $H R$ hazard ratio, $M A C E$ major adverse $\mathrm{CV}$ events, $P B O$ placebo, $Q W$ once weekly

a Not available as of March 2019, pending TGA approval

Although no longer government-reimbursed in Australia, canagliflozin also led to a $14 \%$ reduction in MACE compared with placebo in the CANVAS programme study (Table 4) [49]. The DECLARE-TIMI 58 study supported the CV safety of dapagliflozin in patients with T2DM and established CVD or those with T2DM and $\mathrm{CV}$ risk factors (differing from the more homogenous EMPA-REG OUTCOME cohort) and, unlike canagliflozin and empagliflozin, resulted in a non-significant reduction in the co-primary end point of MACE (Table 4) [51]. Dapagliflozin did result in a lower rate of $\mathrm{CV}$ death or hospitalisation for heart failure vs. placebo (4.9\% vs. $5.8 \%$, respectively; $p=0.005$ ), principally driven by a reduction in admission for heart failure [51]. A meta-analysis of these major trials released, at the same time as DECLARE-TIMI 58 concluded that "SGLT-2 inhibitors have moderate benefits on atherosclerotic MACE that seem confined to patients with established atherosclerotic CVD. However, they have robust benefits on reducing hospitalisation for heart failure and progression of renal disease regardless of existing atherosclerotic CVD or a history of heart failure" [52].
Aside from CV safety, it is important to note that SGLT-2 inhibitors as a class have shown an increased risk of mycotic genital infections and rarely euglycaemic diabetic ketoacidosis [49-51]. The class generally has low rates of hypoglycaemia unless prescribed in conjunction with sulphonylureas or insulin. The risk can be minimised through appropriate patient education and monitoring, such as temporarily ceasing the medication when a patient has an intercurrent illness or dehydration or to stop the medication 3 days before elective surgery/ procedures.

To summarise, unlike DPP-IV inhibitors, specific agents in the GLP-1RAs and SGLT-2 inhibitor classes have been found to confer $\mathrm{CV}$ benefits in variable populations of T2DM patients with established CVD or who are at high risk of a CV event.

\section{SGLT-2 Inhibitors or GLP-1RAs for At-Risk CV Individuals with T2DM?}

With their demonstrable CV safety, combined with their favourable effects on weight and low potential of hypoglycaemia, the recent ADA/ EASD guidelines have recommended GLP-1RAs and SGLT-2 inhibitors as preferred treatment 
Table 4 Summary of SGLT-2 inhibitor CVOTs

\begin{tabular}{|c|c|c|c|}
\hline \multicolumn{4}{|l|}{$\overline{\text { SGLT-2 inhibitors }}$} \\
\hline TGA-approved & Reimbursed & CVOT & CV effect \\
\hline $\begin{array}{l}\text { Canagliflozin [49] } \\
\text { (Invokana) }\end{array}$ & $x$ & $\begin{array}{l}\text { CANVAS programme }(n=9901) \\
\text { High CV risk population } \\
\text { Prior CV event, evidence of CVD or } \\
\geq 2 \mathrm{CV} \text { risk factors } \\
\text { Primary end point: 3-point MACE } \\
\text { Canagliflozin vs. PBO } \\
\text { Superiority and non-inferiority design }\end{array}$ & $\begin{array}{l}\text { Benefit for MACE } \\
\text { Primary end point MACE } \\
\text { HR: } 0.86 \text { ( } 95 \% \text { CI } 0.75-0.97) \\
p<0.001 \text { for noninferiority } \\
p=0.02 \text { for superiority }\end{array}$ \\
\hline $\begin{array}{l}\text { Dapagliflozin [51] } \\
\text { (Forxiga) }\end{array}$ & $\checkmark$ & $\begin{array}{l}\text { DECLARE-TIMI } 58(n=17,160) \\
\text { High CV risk population } \\
\text { History of established CVD or } \\
\text { multiple CVD risk factors } \\
\text { Co primary end points } \\
\text { 1. 3-point MACE } \\
\text { 2. Composite of CV death or } \\
\text { hospitalisation for heart failure } \\
\text { Dapagliflozin vs. PBO }\end{array}$ & $\begin{array}{l}\text { Neutral for MACE } \\
\text { HR: } 0.93 \text { (95\% CI 0.84-1.03); } p=0.17 \\
\text { Benefit for composite of CV death or } \\
\text { hospitalisation for heart failure } \\
\text { HR 0.83; (95\% CI 0.73-0.95); } p=0.005 \\
\text { for superiority }\end{array}$ \\
\hline $\begin{array}{l}\text { Empagliflozin [50] } \\
\text { (Jardiance) }\end{array}$ & $\checkmark$ & $\begin{array}{l}\text { EMPA-REG OUTCOME }(n=7020) \\
\text { High CV risk population } \\
\text { Pre-existing CVD } \\
\text { Primary end point: 3-point MACE } \\
\text { Empagliflozin vs. PBO } \\
\text { Superiority and non-inferiority design }\end{array}$ & $\begin{array}{l}\text { Benefit for MACE } \\
\text { HR } 0.86 \text { (95\% CI } 0.74-0.99) \\
p=0.04 \text { for superiority }\end{array}$ \\
\hline $\begin{array}{r}\text { Ertugliflozin } \\
\text { (Steglatro) }\end{array}$ & $\checkmark$ & NO CVOT reported & Unknown \\
\hline
\end{tabular}

options in addition to metformin for those with established CVD (e.g., patients who had experienced an MI or stroke or had undergone a revascularisation procedure) [30]. In those patients with T2DM and established CVD with co-existing heart failure, or those with T2DM and CKD (with or without CVD), SGLT-2 inhibitors are considered the most appropriate choice unless contraindicated, in which case
GLP-1RAs with proven CV benefits are recommended $[34,53]$. It is worth noting that there are limited data highlighting the glycaemic benefit of combining SGLT-2 inhibitors and GLP-1RA therapies [54, 55]; moreover, the impact of such a combination on CV outcomes is unknown. From an Australian government reimbursement perspective, such combined use is not approved for subsidy at the present time. 


\section{EXPERT GROUP RECOMMENDATIONS ON T2DM MANAGEMENT BASED ON CV AND CKD RISK}

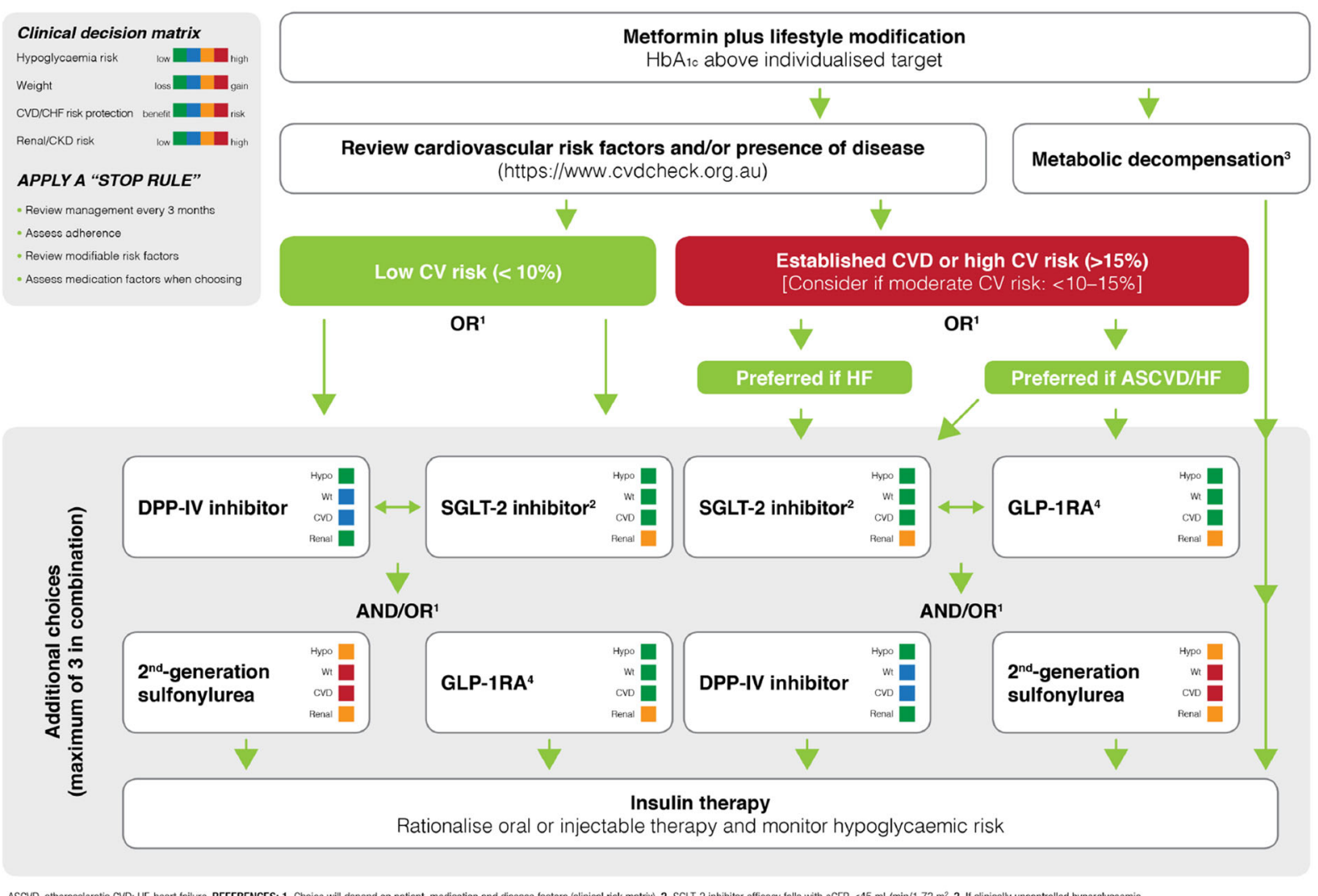

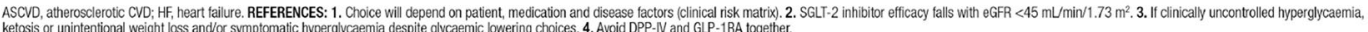

Fig. 1 Treatment algorithm according to $\mathrm{CV}$ and $\mathrm{CKD}$ risk

\section{NAVIGATING COMMON AND COMPLICATED CASE SCENARIOS IN T2DM: EXPERT PERSPECTIVES}

So how should primary practitioners interpret the CVOT data and recent guidelines to inform management of T2DM in primary practice? As informative as these guidelines are, a major gap is understanding how to treat T2DM with multiple $\mathrm{CV}$ risk factors but without established CVD. To address this, a local expert committee that included primary practitioners, a cardiologist and an endocrinologist was convened to identify and discuss case studies of T2DM patients commonly seen in clinical practice who could be stratified according to high, moderate and low CV risk as well as by additional complications such as the presence of
CKD. The key objective was to provide a clinical narrative alongside an algorithm (Fig. 1) that goes beyond glucose-lowering to help guide the treatment decision-making process for each situation.

\section{CASE SCENARIO: HIGH CV RISK PATIENT}

James: a 64-year-old male (ex-smoker) with a 4 -year history of T2DM. This was diagnosed when he had documented triple-vessel disease and underwent coronary artery bypass graft surgery 4 years ago. He recently moved into the area and needed prescriptions. This visit provided an opportunity to review his current medication and management.

Clinical Assessments $\quad \mathrm{HbA}_{1 \mathrm{c}} \quad 7.3 \%$ (56 mmol/mol); eGFR $60 \mathrm{ml} / \mathrm{min} / 1.73 \mathrm{~m}^{2}$; 
weight $92.5 \mathrm{~kg}$; height $1.83 \mathrm{~m}$; BMI $27.6 \mathrm{~kg} / \mathrm{m}^{2}$; total cholesterol 3.9 (LDL 1.82; triglycerides 2.0; HDL 1.03); blood pressure 130/80 mmHg; urine ACR $7.5 \mathrm{mg} / \mathrm{mmol}$.

Existing Medications Aspirin $100 \mathrm{mg}$ once daily; insulin glargine (40 U) and insulin aspart (6 $\mathrm{U}$ at his main meal); rosuvastatin $10 \mathrm{mg}$ once daily; perindopril $5 \mathrm{mg}$ once daily.

\section{Clinical Considerations for James}

James has presented with T2DM with established CVD, which significantly increases his immediate risk of heart failure several-fold as well as premature mortality [56]. Diabetes management needs to focus on optimising ways to reduce these risks. He also has microalbuminuria, which contributes to a greater $\mathrm{CV}$ event rate.

Primary Considerations To prevent future risk of CVD-associated death and heart failure. To achieve an appropriate $\mathrm{HbA}_{1 \mathrm{c}}$ target $(<7 \%$; $53 \mathrm{mmol} / \mathrm{mol}$ ) and optimise his glucose management to prevent the progression of microalbuminuria and renal complications without increasing hypoglycaemia.

How to Manage? To consider where change in therapy may provide additional benefit, e.g., consideration should be focussed on the established CV benefit from newer glucose-lowering agents as well as optimising blood pressure control to further lower risk of heart failure [57].

Which Glucose-Lowering Agent? An agent that may optimise glycaemia, has a low hypoglycaemic profile and a low-to-acceptable clinical risk with proven CVD risk reduction in a patient such as James with a high risk of a CV event. Based on current evidence, an SGLT-2 inhibitor (dapagliflozin, empagliflozin) or GLP-1RA (liraglutide) may be appropriate alternative options as they have demonstrated CV benefits. To note, in clinical trials with patients with a similar presentation, empagliflozin showed a CV mortality benefit while both empagliflozin and dapagliflozin reduced HF hospitalisation $[50,51]$. When selecting SGLT-2 inhibitors, baseline eGFR and the need for ongoing monitoring need to be carefully considered. Of note, dapagliflozin is not indicated for patients with an eGFR $<60 \mathrm{ml} / \mathrm{min} / 1.73 \mathrm{~m}^{2}$, while empagliflozin is not appropriate for patients with an eGFR $<45 \mathrm{ml} / \mathrm{min} / 1.73 \mathrm{~m}^{2}$.

Other Considerations To consider patient profile (lifestyle/adherence), patient preference (oral versus injectable therapy) as well as cost implications (reimbursement criteria) and specific side effect profiles (risks for genitourinary infections).

Following an informed discussion with James and the fact that he is at risk of heart failure and CV death, he expressed a preference for an oral medication. An SGLT-2 inhibitor was therefore prescribed in addition to his existing glucose-lowering medications, and we ceased his prandial (rapid-acting) insulin. He was instructed to monitor his blood glucose and report any hypoglycaemia. The perindopril was increased to $10 \mathrm{mg}$ daily.

\section{Review}

There was no reported hypoglycaemia after an initial monthly review, and then after 3 months, James presented to review his blood investigation result. His $\mathrm{HbA}_{1 \mathrm{c}}$ was now at $6.8 \%$ (51 $\mathrm{mmol} / \mathrm{mol})$, and his weight had dropped to $90.5 \mathrm{~kg}$. He was happy as he was able to cease his meal-time insulin. Home-monitoring of blood pressure showed a reduction to 110/70. He also felt motivated to make some lifestyle changes and had started to do more daily walking.

\section{CASE SCENARIO: MODERATE CV RISK PATIENT}

Chris, a 59-year-old male non-smoker with a 10-year history of T2DM and prior diagnosis of hypertension, presented to his primary practitioner for a routine visit, which provided an opportunity to review his current medication and management of T2DM.

Clinical Assessments $\quad \mathrm{HbA}_{1 \mathrm{c}} \quad 7.6 \%$ (60 mmol/mol); eGFR $\quad 61 \mathrm{ml} / \mathrm{min} / 1.73 \mathrm{~m}^{2}$; weight $101.4 \mathrm{~kg}$; height $1.78 \mathrm{~m}$; BMI $32.0 \mathrm{~kg} /$ $\mathrm{m}^{2}$; total cholesterol 3.8 (LDL 1.99; triglycerides 0.7 ; HDL 1.11); blood pressure $145 / 90 \mathrm{mmHg}$. Urine ACR $<2.5 \mathrm{mg} / \mathrm{mmol}$. 
Existing Medications Atorvastatin $10 \mathrm{mg}$; sitagliptin/metformin 50/850 mg BD; ramipril $5 \mathrm{mg}$ once daily.

\section{Clinical Considerations for Chris}

While Chris has not presented with established CVD, he has several high-risk factors that predispose him to future risk of CVD. The question arises as to how to modify $\mathrm{CV}$ risk in a patient like Chris.

Primary Considerations To optimise glycaemic control for microvascular risk reduction and address any weight issues by optimally assisting with weight loss.

How to Manage? Review self-management and lifestyle modification to assist with weight loss and improved glycaemia. Consider the addition of a glucose-lowering agent with proven CVD safety or positive CVD benefit that also has weight-loss potential.

Which Glucose-Lowering Agent? Based on new research and guidelines [30, 34, 53, 57], an SGLT-2 inhibitor (oral once-daily dapagliflozin, empagliflozin) or a GLP-1RA (once-daily liraglutide, once-weekly dulaglutide) is an appropriate add-on therapy to Chris's current standard-of-care treatment. When selecting SGLT-2 inhibitors, baseline eGFR and the need for ongoing monitoring need to be carefully considered and the risk of euglycaemic diabetes ketoacidosis and uncommon risks such as mild diuresis and mycotic genital infections discussed. When selecting a GLP-1RA, the frequency of injections may alter choice.

Other Considerations To consider patient profile (lifestyle/adherence), patient preference (oral versus injectable therapy) as well as cost implications (reimbursement criteria).

Following an informed discussion with Chris, he expressed preference for an oral, daily medication (dapagliflozin, empagliflozin) as he felt he may forget taking an injection once a week (exenatide QW; dulaglutide). He was not prepared to be out of pocket for the once-daily GLP-1RA option (liraglutide) but was open to using a weekly injection in the future. An SGLT-
2 inhibitor was therefore prescribed. In addition, his existing medications were optimised with the dose of sitagliptin/metformin increased to 50/1000 $\mathrm{mg} \mathrm{BD}$. The dose of ramipril was also increased to $10 \mathrm{mg}$ and it was recommended to be taken at night.

\section{Review}

After 3 months, Chris presented for review. He felt happy as he had managed to get his weight down to below $100 \mathrm{~kg}$. This has spurred him on to set a weight goal of $90 \mathrm{~kg}$. His $\mathrm{HbA}_{1 \mathrm{c}}$ was now $7.1 \%(54 \mathrm{mmol} / \mathrm{mol})$ and he had tolerated the SGLT-2 inhibitor well, with some manageable increased urinary frequency. As he was tolerating the SGLT-2 inhibitor, for cost reasons he was switched to a combination SGLT-2 inhibitor and DPP-IV inhibitor and continued on metformin.

\section{CASE SCENARIO: LOW CV RISK PATIENT}

Gabrielle, a 56-year old female non-smoker with a 7-year history of T2DM, presented to her primary practitioner for a routine visit, which provided an opportunity to review her current medication and management of T2DM.

Clinical Assessments $\quad \mathrm{HbA}_{1 \mathrm{c}} \quad 7.2 \%$ ( $55 \mathrm{mmol} / \mathrm{mol}) ; \quad$ eGFR $90 \mathrm{ml} / \mathrm{min} / 1.73 \mathrm{~m}^{2}$; weight $78 \mathrm{~kg}$; height $1.66 \mathrm{~m}$; BMI $28.3 \mathrm{~kg} / \mathrm{m}^{2}$; total cholesterol 5.8 (LDL 3.2; triglycerides 1.4; HDL 1.2); blood pressure 110/70 $\mathrm{mmHg}$; ACR normal. Absolute CVD risk score reveals Gabrielle to have a low risk of $\mathrm{CV}(6 \%)$.

\section{Clinical Considerations for Gabrielle}

In a younger patient with T2DM there is a need to focus on long-term complication prevention. "Tight" glycaemic control may assist in reducing microvascular risk, but macrovascular risk reduction is equally important. Women with diabetes may in fact have higher long-term risks of ischaemic heart disease compared with aged- 
matched males [58] and a 50\% greater risk of a CV-related fatal outcome [59]. Specific attention to modifiable risk factor reduction is therefore imperative.

Existing Medications Metformin $850 \mathrm{mg}$ BD.

Primary Consideration To proactively manage long-term modifiable $\mathrm{CV}$ risk while managing glycaemia.

How to Manage? To consider individualising "tight' glycaemic management without increasing hypoglycaemia risk and addressing lipid control.

Other Considerations To consider patient profile (lifestyle/adherence), patient preference (formulation) as well as cost implications (reimbursement criteria).

Following an informed discussion and reinforcing the importance of lifestyle modifications, Gabrielle agreed the first step would be to optimise her current medications to improve her glycaemic and lipid levels. We should be concerned about her long-term CVD risk as this is often underestimated in women. Her CVD risk should continue to be monitored and will fall into a high-risk group as she turns 60 . For the time being, changes to her glucose-lowering medications are not considered necessary and she will continue to be monitored.

\section{Review}

After 3 months, Gabrielle presented for review. She was commenced on a DPP-IV inhibitor and achieved a reduction of $\mathrm{HbA}_{1 \mathrm{c}}$ to $6.9 \%$ $(52 \mathrm{mmol} / \mathrm{mol})$. By maintaining a healthier lifestyle, she has also experienced some $2 \mathrm{~kg}$ weight loss and has understood the importance of assessing her cholesterol on an ongoing basis.

\section{CONCLUSIONS}

Individuals with T2DM and who are at an increased risk of $\mathrm{CV}$ and/or CKD can be optimally managed through the addition of selective SGLT-2 inhibitors or GLP-1RAs to their existing standard of care. Treatment choice should be guided by clinical criteria, including the level of CV or CKD risk, as well as individual goals, patient preference for oral or injectable therapies and cost implications of a given treatment for the patient.

\section{ACKNOWLEDGEMENTS}

Funding. This review was funded by Boehringer Ingelheim Australia. All authors had full access to the articles reviewed in this manuscript and take complete responsibility for the integrity and accuracy of this manuscript. No rapid service fee was received by the journal for the publication of this article.

Medical Writing Assistance. Editorial assistance was provided by Dr. Beejal Vyas-Price of McCann Healthcare Australia. Support for this assistance was funded by Boehringer Ingelheim Australia.

Authorship. All named authors meet the International Committee of Medical Journal Editors (ICMJE) criteria for authorship for this article, take responsibility for the integrity of the work as a whole, and have given their approval for this version to be published. The authors would like to thank Dr Jo-Anne ManskiNankervis for review and comments throughout the development of this manuscript.

Disclosures. Gary Deed has received honoraria, speaker fees, consultancy fees, is a member of advisory boards or has appeared on expert panels for: Astra Zeneca, Boehringer Ingelheim, Bristol Myers Squibb, Inova, Lilly, Merck Sharp and Dohm, Novartis, Novo-Nordisk, National Prescriber Service and Sanofi. John Atherton has previously received honoraria, travel sponsorship or consultancy payment from AstraZeneca, Bayer, Boehringer Ingelheim, Bristol-Myers Squibb, Eli Lilly, Menarini, Novartis, Otsuka, Servier and Vifor Pharma. Michael d'Emden has received honoraria for attendance at national advisory boards, presentations and/or support to attend international meetings from Boehringer Ingelheim, Eli Lilly, Astra Zeneca, Novartis, Abbott, Novo Nordisk, Servier and Bayer. Roy Rasalam has received speaker honorarium from Eli Lilly. Anita Sharma has nothing 
to disclose. Andrew Sindone has received honoraria, speaker fees and consultancy fees, is a member of advisory boards or expert panels for: Alphapharm, Aspen, Astra Zeneca, Bayer, Biotronik, Boehringer Ingelheim, Bristol Myers Squibb, HealthEd, Jansen Cilag, Menarini, Merck Sharp and Dohm, Mylan, Novartis, Otsuka, Pfizer, Roche, Sanofi, Servier and Vifor.

Compliance with Ethics Guidelines. This article is based on previously conducted studies and does not contain any studies with human participants or animals performed by any of the authors.

Data Availability. Data sharing is not applicable to this article as no datasets were generated or analysed during the current study.

Open Access. This article is distributed under the terms of the Creative Commons Attribution-NonCommercial 4.0 International License (http://creativecommons.org/licenses/ by-nc/4.0/), which permits any noncommercial use, distribution, and reproduction in any medium, provided you give appropriate credit to the original author(s) and the source, provide a link to the Creative Commons license, and indicate if changes were made.

\section{REFERENCES}

1. International Diabetes Federation. IDF diabetes atlas, 8th edn. Brussels: International Diabetes Federation; 2017. http://www.diabetesatlas.org. Accessed 4 July 2019.

2. Shaw J, Thomas M, Magliano D. The dark heart of type 2 diabetes. Baker Heart and Diabetes Institute. $2017 . \quad$ https://www.baker.edu.au/-/media/ documents/impact/Baker-Institute-The-dark-heartof-type-2-diabetes.ashx?la=en9. Accessed 13 May 2019.

3. Britt H, Miller GC, Henderson J, et al. General practice activity in Australia 2015-16. General practice series no. 40. Sydney: Sydney University Press; 2016. http://purl.library.usyd.edu.au/sup/ 9781743325131. Accessed 13 May 2019.

4. Newton P, Davidson PM, Reidet CM, et al. Acute heart failure admissions in New South Wales and the Australian Capital Territory: the NSW HF Snapshot Study. Med J Aust. 2016;204(113):e1-8.

5. Caughey GE, Vitry AI, Gilbert AL, Roughead EE. Prevalence of comorbidity of chronic diseases in Australia. BMC Public Health. 2008;8:221.

6. Australian Institute of Health and Welfare. Deaths among people with diabetes in Australia, 2009-2014. Cat. no. CVD 79. Canberra: AIHW; 2017.

7. Emerging Risk Factors Collaboration, Sarwar N, Gao $P$, et al. Diabetes mellitus, fasting blood glucose concentration, and risk of vascular disease: a collaborative meta-analysis of 102 prospective studies. Lancet. 2010;375(9733):2215-22.

8. Haffner SM, Lehto S, Ronnemaa $\mathrm{T}$, Pyorala $\mathrm{K}$, Laakso M. Mortality from coronary heart disease in subjects with type 2 diabetes and in nondiabetic subjects with and without prior myocardial infarction. N Engl J Med. 1998;339(4):229-34.

9. Bulugahapitiya U, Siyambalapitiya S, Sithole J, Idris I. Is diabetes a coronary risk equivalent? Systematic review and meta-analysis. Diabet Med. 2009;26(2):142-8.

10. Rana JS, Liu JY, Moffet HH, Jaffe M, Karter AJ. Diabetes and prior coronary heart disease are not necessarily risk equivalent for future coronary heart disease events. J Gen Intern Med. 2016;31(4):387-93.

11. Diabetes: the silent pandemic and its impact on Australia. Baker Heart and Diabetes Institute. 2012. https://baker.edu.au/impact/advocacy/the-silentpandemic. Accessed 13 May 2019.

12. National Vascular Disease Prevention Alliance. Guidelines for the management of absolute cardiovascular disease risk. 2012. Available at: https:// informme.org.au/en/Guidelines/Guidelines-forthe-assessment-and-management-of-absolute-CVDrisk. Accessed 4 July 2019.

13. Holman RR, Paul SK, Bethel MA, Matthews DR, Neil HA. 10-Year follow-up of intensive glucose control in type 2 diabetes. N Engl J Med. 2008;359:1577-89.

14. Nathan DM, Cleary PA, Backlund JY, et al. Intensive diabetes treatment and cardiovascular disease in patients with type 1 diabetes. $\mathrm{N}$ Engl J Med. 2005;22:2643-53.

15. Patel A, MacMahon S, Chalmers J, ADVANCE Collaborative Group, et al. Intensive blood glucose control and vascular outcomes in patients with type 2 diabetes. N Engl J Med. 2008;358:2560-72. 
16. Action to Control Cardiovascular Risk in Diabetes Study Group, Gerstein HC, Miller ME, et al. Effects of intensive glucose lowering in type 2 diabetes. N Engl J Med. 2008;358(24):2545-59.

17. Duckworth W, Abraira C, Moritz T, et al. Glucose control and vascular complications in veterans with type 2 diabetes. N Engl J Med. 2009;360:129-39.

18. Control Group, Turnbull FM, Abraira C, et al. Intensive glucose control and macrovascular outcomes in type 2 diabetes. Diabetologia. 2009;52:2288-98.

19. Ray KK, Seshasai SR, Wijesuriya S, et al. Effect of intensive control of glucose on cardiovascular outcomes and death in patients with diabetes mellitus: a meta-analysis of randomised controlled trials. Lancet. 2009;373:1765-72.

20. Gunton JE, Cheung NW, Davis TME, Zoungas S, Colagiuri S. A new blood glucose management algorithm for type 2 diabetes. A position statement of the Australian Diabetes Society. Med J Aust. 2014;201:650-3.

21. Stratton IM, Adler AI, Neil HAW, et al. Association of glycaemia with macrovascular and microvascular complications of type 2 diabetes (UKPDS 35): prospective observational study. BMJ. 2000;321:405-12.

22. Griffin SJ, Leaver JK, Irving GJ. Impact of metformin on cardiovascular disease: a meta-analysis of randomised trials among people with type 2 diabetes. Diabetologia. 2017;60(9):1620-9.

23. Tahrani AA, Barnett AH, Bailey CJ. Pharmacology and therapeutic implications of current drugs for type 2 diabetes mellitus. Nat Rev Endocrinol. 2016;12:566-92.

24. Varvaki Rados DV, Catani Pinto L, Reck Remonti L, Bauermann Leitão C, Gross JL. The association between sulfonylurea use and all-cause and cardiovascular mortality: a meta-analysis with trial sequential analysis of randomized clinical trials. PLOS Med. 2016;13(4):e1001992. https://doi.org/ 10.1371/journal.pmed.1001992.

25. Gangji AS, Cukierman T, Gerstein HC, Goldsmith $\mathrm{CH}$, Clase CM. A systematic review and meta-analysis of hypoglycemia and cardiovascular events: a comparison of glyburide with other secretagogues and with insulin. Diabetes Care. 2007;30:389-94.

26. Bain S, Druyts E, Balijepalli C, et al. Cardiovascular events and all-cause mortality associated with sulfonylureas compared with other antihyperglycaemic drugs: a Bayesian meta-analysis of survival data. Diabetes Obes Metab. 2017;19(3):329-35.
27. Pladevall $M$, Riera-Guardia N, Margulis AV, VarasLorenzo C, Calingaert B, Perez-Gutthann S. Cardiovascular risk associated with the use of glitazones, metformin and sufonylureas: meta-analysis of published observational studies. BMC Cardiovasc Disord. 2016;16:14.

28. Powell WR, Christiansen CL, Miller DR. Metaanalysis of sulfonylurea therapy on long-term risk of mortality and cardiovascular events compared to other oral glucose-lowering treatments. Diabetes Ther. 2018;9(4):1431-40.

29. Phung OJ, Schwartzman E, Allen RW, Engel SS, Rajpathak SN. Sulphonylureas and risk of cardiovascular disease: systematic review and meta-analysis. Diabet Med. 2013;30(10):1160-71.

30. Press release. Boehringer Ingelheim and Lilly announce the CAROLINA ${ }^{\circledR}$ cardiovascular outcome trial of Tradjenta ${ }^{\circledR}$ met its primary endpoint of noninferiority compared with glimepiride. https:// www.boehringer-ingelheim.us/press-release/ boehringer-ingelheim-and-lilly-announce-carolinacardiovascular-outcome-trial. Accessed 15 Feb 2019.

31. Davies MJ, D'Alessio DA, Fradkin J, et al. Management of hyperglycemia in type 2 diabetes, 2018. A consensus report by the American Diabetes Association (ADA) and the European Association for the Study of Diabetes (EASD). Diabetes Care. 2018;41(12):2669-701.

32. U.S. Food and Drug Administration. Guidance for industry: diabetes mellitus devaluating cardiovascular risk in new antidiabetic therapies to treat type 2 diabetes. 2008. https://www.fda.gov/downloads/ Drugs/Guidances/ucm071627.pdf. Accessed 20 Aug 2018.

33. European Medicines Agency. Guideline on clinical investigation of medicinal products in the treatment or prevention of diabetes mellitus. 2012. http://www.ema.europa.eu/docs/en_GB/ document_library/Scientific_guideline/2012/06/ WC500129256.pdf. Accessed 20 Aug 2018.

34. Cefalu WT, et al. Cardiovascular outcomes trials in type 2 diabetes: where do we go from here? Diabetes Care. 2018;41:14-31.

35. American Diabetes Association. 9. Cardiovascular disease and risk management: standards of medical care in diabetes. 2018. Diabetes Care. 2018;41(Suppl. 1):S86-104.

36. Diabetes Canada. Clinical practice guidelines. 2018. http://guidelines.diabetes.ca/cpg. Accessed 4 July 2019. 
37. Mancini GR, Hegele RA, Leiter LA. 2018 clinical practice guidelines; dyslipidemia. Can J Diabetes. 2018;42:S178-85.

38. NHFA CSANZ Atrial Fibrillation Guideline Working Group, Brieger D, Amerena J, et al. National Heart Foundation of Australia and the Cardiac Society of Australia and New Zealand: Australian clinical guidelines for the diagnosis and management of atrial fibrillation 2018. Heart Lung Circ. 2018;27(10):1209-66.

39. Scirica BM, Bhatt DL, Braunwald E, et al. Saxagliptin and cardiovascular outcomes in patients with type 2 diabetes mellitus. $\mathrm{N}$ Engl J Med. 2013;369:1317-26.

40. Scirica B, Braunwald E, Raz I, et al. Heart failure, saxagliptin, and diabetes mellitus: observations from the SAVOR-TIMI 53 randomized trial. Circulation. 2014;130:1579-88.

41. White WB, Cannon CP, Heller SR, et al. Alogliptin after acute coronary syndrome in patients with type 2 diabetes. N Engl J Med. 2013;369:1327-35.

42. Zannad F, Cannon CP, Cushman WC, et al. Heart failure and mortality outcomes in patients with type 2 diabetes taking alogliptin versus placebo in EXAMINE: a multicentre, randomised, doubleblind trial. Lancet. 2015;385:2067-76.

43. Marso SP, Bain SC, Consoli A, et al. Semaglutide and cardiovascular outcomes in patients with type 2 diabetes. N Engl J Med. 2016;375:1834-44.

44. Pfeffer MA, Claggett B, Diaz R, et al. Lixisenatide in patients with type 2 diabetes and acute coronary syndrome. N Engl J Med. 2015;373:2247-57.

45. Holman RR, Bethel MA, Mentz RJ, et al. Effects of once-weekly exenatide on cardiovascular outcomes in type 2 diabetes. N Engl J Med. 2017;377:1228-39.

46. Marso SP, Daniels GH, Brown-Frandsen K, et al. Liraglutide and cardiovascular outcomes in type 2 diabetes. N Engl J Med. 2016;375:311-22.

47. Gerstein HC, Colhoun HM, Dagenais GR, et al. Design and baseline characteristics of participants in the Researching cardiovascular Events with a Weekly INcretin in Diabetes (REWIND) trial on the cardiovascular effects of dulaglutide. Diabetes Obes Metab. 2018;20(1):42-9.

48. Press Release. Trulicity ${ }^{\circledR}$ (dulaglutide) demonstrates superiority in reduction of cardiovascular events for broad range of people with type 2 diabetes. https:// investor.lilly.com/news-releases/news-releasedetails/trulicityr-dulaglutide-demonstratessuperiority-reduction. Accessed 5 Nov 2018.
49. Neal B, Perkovic V, Mahaffey KW, et al. Canagliflozin and cardiovascular and renal events in type 2 diabetes. N Eng J Med. 2017;377:644-57.

50. Zinman B, Wanner C, Lachin JM, et al. Empagliflozin, cardiovascular outcomes, and mortality in type 2 diabetes. N Engl J Med. 2015;373:2117-28.

51. Raz I, Mosenzon O, Bonaca MP, et al. DECLARETIMI 58: participants' baseline characteristics. Diabetes Obes Metab. 2018;20(5):1102-10.

52. Zelnicker TA, Wiviott SD, Raz I, et al. SGLT2 inhibitors for primary and secondary prevention of cardiovascular and renal outcomes in type 2 diabetes: a systematic review and meta-analysis of cardiovascular outcome trials. Lancet. 2019;393(10166):31-9.

53. Das SR, Everett BM, Birtcher KK, et al. 2018 ACC expert consensus decision pathway on novel therapies for cardiovascular risk reduction in patients with type 2 diabetes and atherosclerotic cardiovascular disease: a report of the American College of Cardiology Task Force on Expert Consensus Decision Pathways. J Am Coll Cardiol. 2018;72(24):3200-23.

54. Frias JP, Guja C, Hardy E, et al. Exenatide once weekly plus dapagliflozin once daily versus exenatide or dapagliflozin alone in patients with type 2 diabetes Inadequately controlled with metformin monotherapy (DURATION-8): a 28 week, multicentre, double-blind, phase 3, randomised controlled trial. Lancet Diabetes Endocrinol. 2016;4:1004-16.

55. Ludvik B, Frías JP, Tinahones FJ, et al. Dulaglutide as add-on therapy to SGLT2 inhibitors in patients with inadequately controlled type 2 diabetes (AWARD-10): a 24-week, randomised, double-blind, placebo-controlled trial. Lancet Diabetes Endocrinol. 2018;6(5):370-81.

56. Dhingra R, Vasan RS. Diabetes and the risk of heart failure. Heart Fail Clin. 2011;8(1):125-33.

57. Atherton JJ, Sindone A, De Pasquale CG, et al. National Heart Foundation of Australia and Cardiac Society of Australia and New Zealand: Australian clinical guidelines for the management of heart failure 2018. Med J Aust. 2018;209(8):363-9.

58. McSweeney JC, Rosenfeld AG, Abel WM, et al. Preventing and experiencing ischemic heart disease as a woman: state of the science: a scientific statement from the American Heart Association. Circulation. 2016;133(13):1302-31.

59. Huxley R, Barzi F, Woodward M. Excess risk of fatal coronary heart disease associated with diabetes in 
men and women: meta-analysis of 37 prospective cohort studies. BMJ. 2006;332(7533):73-8.

60. Cornell JB, Bethel MA, Armstrong PW, et al. Effect of sitagliptin on cardiovascular outcomes in type 2 diabetes. N Engl J Med. 2015;373:232-42.
61. Rosenstock J, Perkovic V, Johansen OE, et al. Effect of linagliptin vs placebo on major cardiovascular events in adults with type 2 diabetes and high cardiovascular and renal risk: the CARMELINA randomized clinical trial. JAMA. 2019;321(1):69-79. 